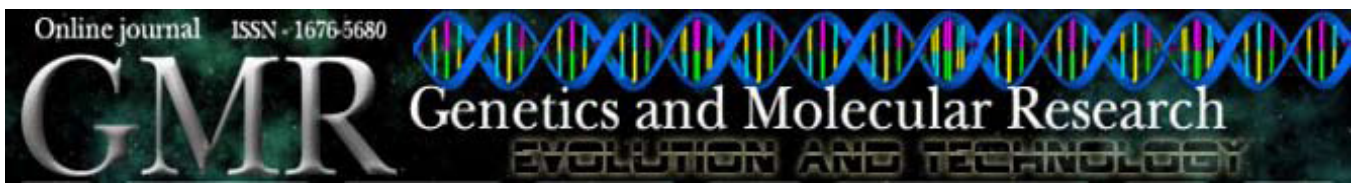

\title{
Optimization of DNA extraction from seeds and fresh leaf tissues of wild marigold (Tagetes minuta) for polymerase chain reaction analysis
}

\author{
I. Shahzadi, R. Ahmed, A. Hassan and M.M. Shah \\ Biotechnology Program, Department of Environmental Sciences, \\ COMSATS Institute of Information Technology, Abbottabad, Pakistan \\ Corresponding author: M.M. Shah \\ E-mail: mmshah@ciit.net.pk
}

Genet. Mol. Res. 9 (1): 386-393 (2010)

Received November 25, 2009

Accepted December 14, 2009

Published March 9, 2010

\begin{abstract}
Tagetes, a genus of flowering marigolds in the family Asteraceae (Compositeae), is reported to be a medicinal plant with hypotensive, spasmolytic, anti-inflammatory, antimicrobial, and antifungal properties. Tagetes minuta characteristically contains high concentrations of essential oils, flavonoids, polyphenols, and polysaccharides that interfere with DNA, causing erroneous or no PCR products. We tested and modified various standard protocols in an effort to isolate high-quality DNA from different plant tissues of T. minuta. We used sun-dried, shade-dried and fresh-leaf tissues, as well as seeds for DNA analysis. The DNA obtained from seeds and fresh-leaf tissues with a modified cetyltrimethylammonium bromide buffer protocol was of good quality, with no colored pigments and contaminants. We were able to obtain good quality DNA from fresh leaf tissues without using liquid nitrogen. A relatively large amount of DNA was also extracted from the sun- and shadedried tissues, but its quality was not as good as that from seeds. The DNA extracted from seeds and fresh leaves was successfully amplified by PCR using arbitrary RAPD primers. The same protocol
\end{abstract}


will probably be useful for extracting high-molecular weight DNA from other plant materials containing large amounts of secondary metabolites and essential oils.

Key words: DNA; Essential oil; PCR amplification; RAPDs; Tagetes minuta

\section{INTRODUCTION}

Wild marigold (Tagetes minuta L.) locally known as 'Gul-e-Sad Barga' is an annual member of the Asteraceae (Compositeae) family, probably originated from South America, and was later introduced to Central America, Europe, Australia and Eastern and Southern Africa. The genus Tagetes includes 56 species (Soule, 1993b), which are grown widely all over the world for various uses including ornamental, medicinal, cultural, therapeutic, and dye-producing plant species. It is also considered to be a noxious weed in parts of southern Africa and other parts of the world. This plant is growing on a broad spectrum of environments starting from extreme temperate to tropical regions of the world. The plant grows to a height of $50-150 \mathrm{~cm}$ with a single, highly branched stem at the top. In tropics and especially in Brazil and adjoining regions it is grown for essential oil production (Lawrence, 1985), which has numerous applications for the benefits of human society. The oils are good insect repellents and are used in the treatment of certain illnesses, such as smallpox, earache, and colds and to reduce fevers (Mangena and Muyima, 1999). Tagetes oil, which can be extracted with hexane (Wiese et al., 1992), is an established product of flavor and a raw material for perfume production (Soule, 1993a). The oil is a rich source of limonene, ocimene, dihydrotagetone, tagetone, and tagetenone (Kaul et al., 2005).

At current state of knowledge, DNA analyses are an essential component for understanding organisms at molecular level. The quick, reliable and inexpensive protocols for DNA isolation are always desirable. DNA extracted from processed materials from Tagetes species is usually degraded or contaminated by essential oils, polyphenols and tagetones and thus generates no polymerase chain reaction (PCR) or restriction products upon amplification or digestions. In general, it is difficult to extract and purify high-quality DNA from medicinal plants because of the presence of large quantities of secondary metabolites, polysaccharides and proteins such as tannins, alkaloids, and polyphenols. These compounds interfere by precipitating along with the DNA, thus degrading its quality and reducing yield (Katterman and Shattuck, 1983; Sarwat et al., 2006). An array of DNA isolation protocols have been optimized and were used in various combinations to isolate quality DNA from plants for analyses (Dellaporta et al., 1983; Doyle and Doyle, 1990; Suman et al., 1999; Shah et al, 2000; Warude et al., 2003; Sarwat et al., 2006; Deshmukh et al., 2007). Liquid nitrogen has been extensively used for DNA extraction from fresh leaf and or other tissues, which is assumed to be a key factor of obtaining clean and of better quality DNA from fresh leaf tissues. However, it is not always easily available or convenient to use especially in developing parts of the world. Our objective was to develop a DNA extraction protocol without using liquid nitrogen for dry and fresh plant tissues including seeds of Tagetes species to obtain high-quality DNA that is suitable for amplification by means of PCR. 


\section{MATERIAL AND METHODS}

\section{Plant material}

The fresh and dried leaves and seeds were used to isolate the DNA from T. minuta. The plants were grown at research farm of the COMSATS Institute of Information Technology in Abbottabad using seeds collected from the plains and hilly areas of Hazara Division, Pakistan. Leaf tissues were collected upon 6-8 leaved stage. The young leaf tissues were taken to the laboratory in an icebox and were used directly to isolate DNA by crushing in the extraction buffer. A portion of the leaves were subjected to sun-drying by placing on clean mesh under sun in the farm. For shade drying the samples were brought to the labs or store houses and were shade-dried by placing on the tables. Seeds of T. minuta were collected from the farm grown plants and also from other parts and were stored in zipper bags in the laboratory. Three major protocols, for ex., isoamylalcohol, cetyltrimethylammonium bromide (CTAB), and sodium dodecyl sulfate (SDS), were used with modifications to isolate and analyze DNA from $T$. minuta using different tissue types. A modified CTAB buffer method (Kim and Hamada, 2005) was employed to post-extraction analyses of DNA from seed and leaf tissues.

\section{Reagents and chemicals}

- $\quad$ 1.0 M Tris- $\mathrm{Cl}(\mathrm{pH} 8.0,9.5) ; 0.5 \mathrm{M}$ EDTA (pH 8); $5.0 \mathrm{M} \mathrm{NaCl} ; 3.0 \mathrm{M}$ sodium acetate (pH 5.2); CTAB (20\%); chloroform:isoamyl alcohol (24:1, v/v); $\beta$-mercaptoethanol (AR grade)

- $\quad$ Modified CTAB extraction buffer: 0.1 M Tris-Cl (pH 9.5), 20 mM EDTA (pH 8), 1.4 M NaCl, CTAB (2\%, w/v), $\beta$-mercaptoethanol ( $1 \%$, v/v) (added to the buffer just before use)

- Pure cold $\left(-20^{\circ} \mathrm{C}\right)$ isopropanol

- $70 \%$ ethanol

- Absolute ethanol

- TE buffer: 10 mM Tris-Cl buffer (pH 8.0), 1 mM EDTA (pH 8.0)

- Enzyme: Taq DNA polymerase (Fermentas Inc.), Rnase A (Fermentas Inc.)

- Buffer: Taq DNA polymerase buffer (Fermentas Inc.)

- Nucleotides: dNTPs (G, A, T, C) and RAPD primers (GL A1-10)

- TBE 5X: $54 \mathrm{~g}$ Tris, $27.5 \mathrm{~g}$ boric acid, $20 \mathrm{~mL} 0.5 \mathrm{M}$ EDTA

- Agarose gel

- Ethidium bromide

\section{DNA extraction}

1. Fresh-leaf tissue $(0.2 \mathrm{~g})$ was ground in a 1.5 -mL Eppendorf tube with a micropestle and preheated freshly prepared $800 \mu \mathrm{L}$ extraction buffer was immediately added to the tube.

2. Seeds, sun-dried and shade-dried leaf samples $(0.1 \mathrm{~g})$ were grounded to fine powder with a pestle and mortar and transferred to a 1.5-mL Eppendorf tube and $800 \mu \mathrm{L}$ extraction buffer was added.

3. Incubation at $65^{\circ} \mathrm{C}$ for $35-45 \mathrm{~min}$, with inversion during incubation. 
4. An equal volume of chloroform:isoamyl alcohol $(24: 1, \mathrm{v} / \mathrm{v})$ was added and then the tubes were inverted 8-10 times.

5. The tubes were centrifuged at 13,000 rpm for $15 \mathrm{~min}$.

6. The supernatant was placed in a new Eppendorf tube.

7. If there was precipitation, then steps 4-6 were repeated until the precipitate was removed.

8. An equal volume of absolute ice-cold isopropanol was added.

9. The tubes were centrifuged at $13,000 \mathrm{rpm}$ for $10 \mathrm{~min}$.

10. The supernatant was discarded and the pellet was washed with $70 \%(\mathrm{v} / \mathrm{v})$ ethanol.

11. The pellet was air-dried for $1 \mathrm{~h}$ at room temperature and then dissolved in 100 $\mu \mathrm{L}$ TE buffer.

12. RNase $\mathrm{A}[2 \mu \mathrm{L}(1 \mu \mathrm{g} / \mu \mathrm{L})]$ was added and the tubes were incubated at $37^{\circ} \mathrm{C}$ for $1 \mathrm{~h}$.

13. For further purification, extraction with an equal volume of chloroform:isoamyl alcohol $(24: 1, \mathrm{v} / \mathrm{v})$ was performed.

14. DNA was precipitated by adding $1 / 10$ th volume of $3 \mathrm{M}$ sodium acetate, $\mathrm{pH} 5.2$, and 2.5 volume of ice-cold ethanol; the tube was inverted gently and this mixture maintained for $30 \mathrm{~min}$ at $-20^{\circ} \mathrm{C}$. It was then centrifuged at $13,000 \mathrm{rpm}$ for $10 \mathrm{~min}$.

15. The supernatant was discarded and the pellet was washed with $70 \%(\mathrm{v} / \mathrm{v})$ ethanol.

16. The pellet was dried and dissolved in $100 \mu \mathrm{L}$ TE buffer.

17. DNA concentrations were measured by running aliquots on $0.8 \%$ agarose gel and by reading absorbance at $260 \mathrm{~nm}$ with a spectrophotometer.

18. The DNA samples were stored at $-20^{\circ} \mathrm{C}$ until further use.

\section{PCR amplification and gel electrophoresis}

PCR-based amplification of the purified DNA was carried out in a $20-\mu \mathrm{L}$ reaction mixture. The reaction mixture contained $25 \mathrm{ng}$ template DNA, 0.125-U Taq DNA polymerase, $1.6 \mathrm{mM}$ dNTPs, $3.75 \mathrm{mM} \mathrm{MgCl}_{2}$, 1X Taq DNA polymerase buffer (Shah et al., 2000) and $2 \mathrm{mM}$ Primer (GL, USA). Amplification of the DNA was done using a Perkin Elmer 9700 thermocycler (ABI, Foster City, CA, USA) with the following parameters: initial denaturation at $94^{\circ} \mathrm{C}$ for $5 \mathrm{~min}$, followed by 35 cycles of denaturation at $94^{\circ} \mathrm{C}$ for $30 \mathrm{~s}$, primer annealing at $50^{\circ} \mathrm{C}$ for $1 \mathrm{~min}$, and extension at $72^{\circ} \mathrm{C}$ for $1 \mathrm{~min}$, with a final extension at $72^{\circ} \mathrm{C}$ for $7 \mathrm{~min}$. The reaction was stored at $4^{\circ} \mathrm{C}$, until it was loaded onto the gel. The PCR products were fractionated on $0.8 \%$ agarose gel using $1 \mathrm{X}$ TBE buffer containing $10 \mathrm{mg} / \mathrm{mL}$ ethidium bromide and were visualized under UV light and the gels were photographed using the UVi-tec gel documentation system (Ghafoor et al., 2007).

\section{RESULTS AND DISCUSSION}

We tested various protocols and their modifications that were developed and employed to isolate quality DNA from different plant species in the past (Murray and Thompson, 1980; Dellaporta et al., 1983; Saghai-Maroof et al., 1984; Rogers and Bendich, 1985; Doyle and Doyle, 1990; Suman et al., 1999; Warude et al., 2003; Sarwat et al., 2006; Deshmukh et al., 2007). Three of the reported protocols (isoamylalcohol, CTAB, and SDS) were particularly used (with modifications) to isolate and analyze DNA from T. minuta using different tissue types. The major aim was to optimize a protocol that may be rapid and inexpensive with high quality and 
throughput. T. minuta is one of those medicinal plant species that contain higher levels of secondary metabolites such as polysaccharides, polyphenols, flavonoids, and essential oils, which may get co-precipitated with DNA during its preparation, thus interfering with enzymatic analysis. The removal of such compounds is a key to obtain good-quality DNA. The DNA isolated using various extraction protocols was compared from preparation to PCR analysis in terms of quantity and quality. The DNA obtained was not of enough quantity and the quality was very poor especially in case of dried leaf tissues in all the tested protocols. The preparations (including DNA) in the test tubes were highly viscous and dirty brown in color, which showed no or very faint bands (or smears of the bands) upon gel electrophoresis while there were no amplification products after PCR analysis. However, the results from the modified CTAB buffer method were encouraging and were far better than the rest of the tested protocols especially in case of fresh leaf tissues without liquid nitrogen and the seed samples. In that point, we have stopped further testing for the protocols except CTAB procedure. The modified CTAB buffer method of genomic DNA extraction from different tissues of $T$. minuta was further tested and refined to compare its efficiency in terms of quantity and quality of the DNA for various tissue types.

We report the successful DNA extraction from fresh, sun-dried, shade-dried leaf tissues, and powdered (paste) seeds. The DNA obtained from sun- and shade-dried leaves was not of adequate quality for PCR analyses. The DNA concentration was measured in a spectrophotometer (UV/VIS), and an absorbance, i.e., $\mathrm{A}_{260} / \mathrm{A}_{280}$ ratio of 1.3, was obtained indicating high levels of contaminated proteins and polysaccharides. Total DNA isolated from fresh leaves and dried-seed powder of T. minuta was checked by means of agarose gel electrophoresis. High-molecular weight DNA of larger quantities and of good quality was obtained from fresh leaves without using liquid nitrogen and dried seed samples (Figures 1, and 2). The purity of the DNA samples was confirmed by absorbance $\left(\mathrm{A}_{260} / \mathrm{A}_{280}\right)$ ratio, which was 1.8 . The modified protocol thus yielded DNA of high purity, free from essential oils, polyphenols, flavonoides, and polysaccharides from fresh leaf samples and seed tissues. However, an increase in the amount of tissues used did not increase DNA yield from either types of plant tissues. The DNA obtained was suitable for enzymatic manipulations such as PCR and showed high intensity amplification with arbitrary RAPD primers (Figures 3,4 , and 5). PCR amplification also indicates that the DNA was of good quality, free from interfering compounds, and it would be suitable for other DNA analyses such as restriction, Southern transfer and hybridization when performing restriction fragment length polymorphism (RFLP).

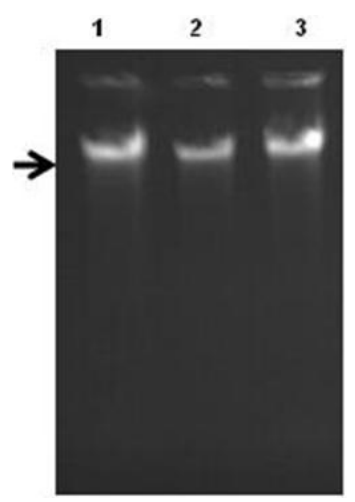

Figure 1. Ethidium bromide-stained agarose gel showing total DNA isolated from three samples of fresh leaf tissue of Tagetes minuta (lanes 1, 2 and 3). 


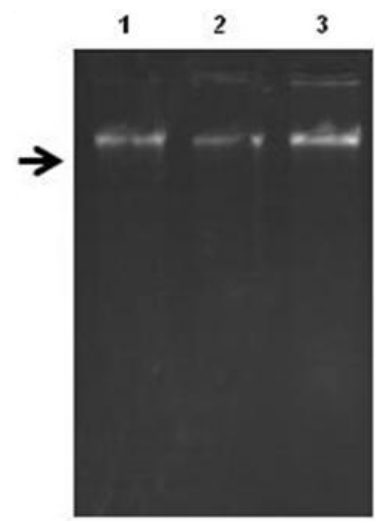

Figure 2. Ethidium bromide-stained agarose gel showing total DNA isolated from three samples of dried seed powder of Tagetes minuta (lanes 1, 2 and 3).

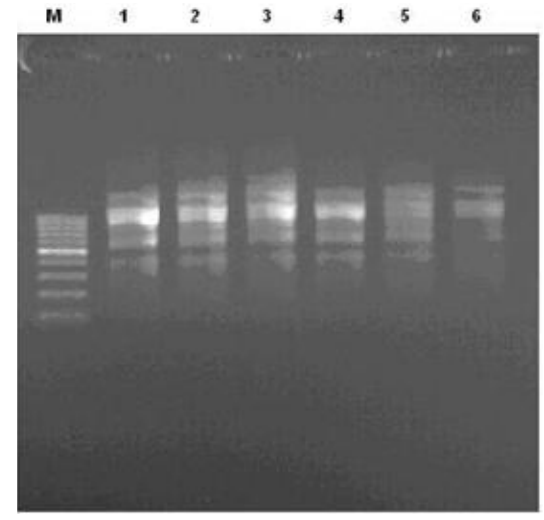

Figure 3. Ethidium bromide-stained agarose gel showing PCR-amplified products obtained from DNA isolated from fresh-leaf tissue by using random primers. M: 100-bp DNA ladder; lanes 1, 2, and 3: Tagetes minuta DNA amplified with primer GL A-03; lanes 4, 5, and 6: T. minuta seed tissue DNA amplified with primer GL A-03.

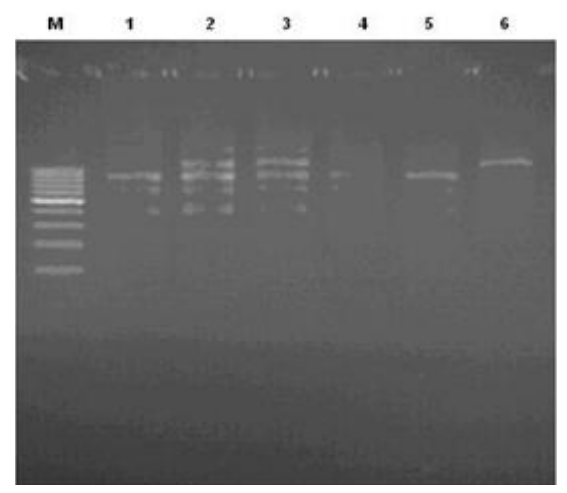

Figure 4. Ethidium bromide-stained agarose gel showing PCR-amplified products obtained from DNA isolated from fresh-leaf tissue by using random primers. M: 100-bp DNA ladder; lanes 1, 2, and 3: Tagetes minuta DNA amplified with primer GL A-08; lanes 4, 5, and 6: T. minuta seed tissue DNA amplified with primer GL A-08. 


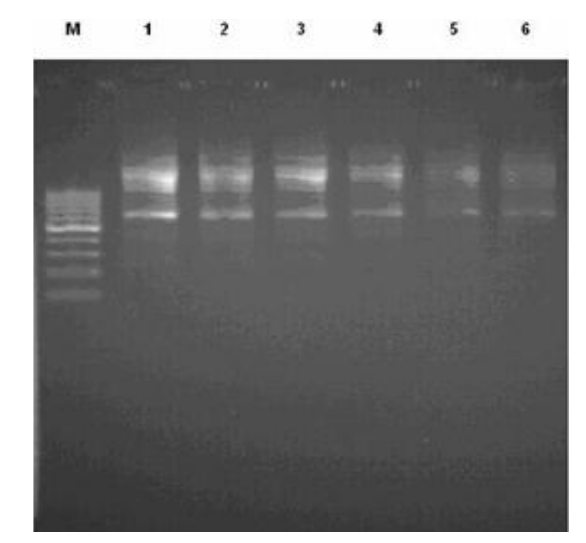

Figure 5. Ethidium bromide-stained agarose gel showing PCR-amplified products obtained from DNA isolated from fresh-leaf tissue by using random primers. M: 100-bp DNA ladder; lanes 1, 2, and 3: Tagetes minuta DNA amplified with primer GL A-09; lanes 4, 5, and 6: T. minuta seed tissue DNA amplified with primer GL A-09.

DNA isolation is a primary and critical step for molecular analysis of any plant species. This process becomes even more difficult when the plant species contain high amounts of secondary metabolites and essential oils. These compounds, particularly in medicinal plants, are considered to be as contaminants that cause DNA degradation during preparation. T. minu$t a$ is one of such plant species and therefore the extraction of genomic DNA from this plant is difficult. Polyvinylpyrrolidone (PVP), a compound known to suppress polyphenolic oxidation, has been used frequently in CTAB extraction protocols (Doyle and Doyle, 1990). The modified CTAB buffer containing PVP was also employed to extract DNA from T. minuta using liquid nitrogen (Hills and Van Staden, 2002). However, it is reported elsewhere that this compound did not significantly increase the yield or prevent contamination of the DNA (Schneerman et al., 2002). SDS-based extraction buffer is being used to break open the cells and isolate DNA. But the quality of DNA obtained is questioned due to precipitation of polysaccharides and proteins. In addition, the SDS might not bind with the proteins in the purification step, thus degrading the extracted DNA (Aljanabi et al., 1999; Deshmukh et al., 2007). Since SDS and isoamylalcohol methods did not give significant results in either type of leaf tissues or seeds that we tested in the case of T. minuta, it is therefore hard to make any conclusive comments on their efficacy or effectiveness. However, the use of PVP in CTAB buffer did not improve the yield or quality rather we obtained significantly better results without its use in our experiment of DNA extraction.

Most of the protocols that we tested recommend extraction of DNA from fresh tissues, but sometimes samples collected from remote and rare locations consist of plant parts in dry or semi-dry conditions. Also, for some areas of the world, the chemicals and resources that are routinely used in many protocols are too expensive to be used for routine DNA extraction. Therefore, it was necessary to establish an inexpensive and less time-consuming protocol for DNA extraction from various plant parts. We also tested seeds for extraction of DNA because T. minuta is an annual medicinal species and seeds are easily preserved in plastic bags for a long time without specific preserving conditions. High-quality DNA was obtained from seeds 
or fresh leaves of T. minuta for post-extraction enzymatic analysis. We anticipate that this protocol will be adequate for extracting high-molecular weight DNA from other species containing large amounts of secondary metabolites and essential oils.

\section{REFERENCES}

Aljanabi SM, Forget L and Dookun A (1999). An improved and rapid protocol for the isolation of polysaccharide- and polyphenol-free sugarcane DNA. Plant Mol. Biol. Rep. 17: 1-8.

Dellaporta SL, Wood J and Hicks JB (1983). A plant DNA minipreparation: Version II. Plant Mol. Biol. Rep. 1: 19-21.

Deshmukh VP, Thakare PV, Chaudhari US and Gawande PA (2007). A simple method for isolation of genomic DNA from fresh and dry leaves of Terminalia arjuna (Roxb.) Wight and Argot. Electron. J. Biotechnol. 10: 468-472.

Doyle JJ and Doyle JL (1990). Isolation of plant DNA from fresh tissue. Focus 12: 13-15.

Ghafoor S, Shah MM, Ahmad H, Swati ZA, et al. (2007). Molecular characterization of Ephedra species found in Pakistan. Genet. Mol. Res. 6: 1123-1130.

Hills PN and Van Staden J (2002). An improved DNA extraction procedure for plant tissues with a high phenolic content. S. Afr. J. Bot. 68: 549-550.

Katterman FR and Shattuck VI (1983). An effective method of DNA isolation from the mature leaves of Gossypium species that contain large amounts of phenolic terpenoids and tannins. Prep. Biochem. 13: 347-359.

Kaul PN, Bhattacharya AK, Rao BRR, Syamasundar KV, et al. (2005). Essential oil composition of Tagetes minuta L. fruits. J. Essent. Oil Res. 17: 184-185.

Kim SH and Hamada T (2005). Rapid and reliable method of extracting DNA and RNA from sweetpotato, Ipomoea batatas (L). Lam. Biotechnol. Lett. 27: 1841-1845.

Lawrence BM (1985). A review of the world production of essential oils - 1984. Perfumer Flavorist 10: 1-16.

Mangena T and Muyima NY (1999). Comparative evaluation of the antimicrobial activities of essential oils of Artemisia afra, Pteronia incana and Rosmarinus officinalis on selected bacteria and yeast strains. Lett. Appl. Microbiol. 28: 291-296.

Murray MG and Thompson WF (1980). Rapid isolation of high molecular weight plant DNA. Nucleic Acids Res. 8: 4321-4325.

Rogers SO and Bendich AJ (1985). Extraction of DNA from milligram amounts of fresh, herbarium and mummified plant tissues. Plant Mol. Biol. 5: 69-76.

Saghai-Maroof MA, Soliman KM, Jorgensen RA and Allard RW (1984). Ribosomal DNA spacer-length polymorphisms in barley: Mendelian inheritance, chromosomal location, and population dynamics. Proc. Natl. Acad. Sci. U. S. A. 81: 8014-8018.

Sarwat M, Negi MS, Lakshmikumaran M, Tyagi AK, et al. (2006). A standardized protocol for genomic DNA isolation from Terminalia arjuna for genetic diversity analysis. Electron. J. Biotechnol. 9: 86-91.

Schneerman MC, Mwangi J, Hobart B, Arbuckle J, et al. (2002). The dried corncob as a source of DNA for PCR analysis. Plant Mol. Biol. Rep. 20: 59-65.

Shah MM, Yen Y, Gill KS and Baenziger PS (2000). Comparisons of RFLP and PCR-based markers to detect polymorphism between wheat cultivars. Euphytica 114: 135-142.

Soule JA (1993a). Tagetes minuta: Potential New Herbs from South America. In: New Crops (Janick J and Simon JE, eds.). Wiley, New York, 649-654.

Soule JA (1993b). Medicinal and beverage uses of Tagetes (Tageteae: Compositae). Am. J. Bot. 80: 177.

Suman PSK, Ajit KS, Darokar MP and Kumar S (1999). Rapid isolation of DNA from dry and fresh samples of plants producing large amounts of secondary metabolites and essential oils. Plant Mol. Biol. Rep. 17: 1-7.

Warude D, Chavan P, Joshi K and Patwardhan B (2003). DNA isolation from fresh, dry plant samples with highly acidic tissue extracts. Plant Mol. Biol. Rep. 21: 467.

Wiese B, Quiroga OE, Vigo MS and Nolasco SM (1992). Seeds of Tagetes minuta L. chemical composition of seed oil and residual seed meal. [Semilla de Tagete minuta L. composición química del aceite seminal y de la harina residual de extracción]. An. Asoc. Quím. Argent. 80: 487-491. 